\section{The saga of} psychoanalysis in Eastern Europe: repression and rebirth in Hungary, and in former Czechoslovakia and Yugoslavia

\section{A saga da psicoanálise no leste eutopeu: repressão e renascimento na Hungria e nas antigas Tchecoslováquia e Iugoslávia}

\section{Judit Mészáros}

Honorary professor, Faculty of Education and Psychology/ Eötvös Loránd University; training and supervising psychoanalyst, Hungarian Psychoanalytical Society.
1075 Budapest, Kazinczy utca, 23-27
1056 - Budapest - Hungary
judit@juditmeszaros.com

Received for publication in September 2016. Approved for publication in February 2017.

http://dx.doi.org/10.1590/\$0104-59702017000400007
MÉSZÁROS, Judit. The saga of psychoanalysis in Eastern Europe: repression and rebirth in Hungary, in former Czechoslovakia, and Yugoslavia. História, Ciências, Saúde - Manguinhos, Rio de Janeiro, v.24, supl., nov. 2017, p.91-103.

\section{Abstract}

The paper shortly presents the early roles of Budapest, Prague, and Belgrade in the development of psychoanalytic movement in Central-Europe before the Second World War. Mapping this historical heritage, it suggests how psychoanalysts of former Soviet Bloc countries could restore their own psychoanalytic communities. The study investigates the consequences of these dictatorial and authoritarian regimes for psychoanalysis and for psychoanalysts focusing on similarities and differences in Hungary, in former Czechoslovakia, and Yugoslavia. Furthermore, it emphasizes the contribution of the international professional organizations - the International Psychoanalytic Association, and the European Psychoanalytic Federation - for reintegration of Budapest, Prague, and Belgrade to the international psychoanalytic community.

Keywords: historical antecedents; exile; separation; self-esteem; reintegration.

\section{Resumo}

O artigo apresenta brevemente os papéis de Budapeste, Praga e Belgrado no desenvolvimento do movimento psicoanalítico na Europa central antes da Segunda Guerra Mundial. Mapeando essa herança histórica, o artigo sugere como psicanalistas do antigo bloco soviético puderam restaurar suas próprias comunidades psicoanalíticas. O estudo investiga as consequências desses regimes ditatoriais e autoritários para a psicanálise e para os psicanalistas focalizando as semelhanças e diferenças na Hungria e nas antigas Tchecoslováquia e Iugoslávia. Além disso, destaca a contribuição das organizações profissionais internacionais - a International Psychoanalytic Association e a European Psychoanalytic Federation - na reintegração de Budapeste, Praga e Belgrado à comunidade psicoanalítica internacional.

Palavras-chave: antecedentes históricos; exílio; separação; auto-estima; reintegração. 
"A certain level of political and social freedom would be a precondition for a successful implantation of psychoanalysis" (Plotkin, Damousi, 2012, p.XVII). Can psychoanalysis exist under conditions of political authoritarianism? In order to contribute to this discussion, in this article I compare and contrast the history of the psychoanalytic movement as well as its suppression and revival in three former Soviet Bloc countries.

Although there were considerable variations in psychoanalytic history from country to country before World War II, I will show the common denominators on institutional and individual levels. These include difficulties establishing or re-establishing psychoanalytic organizations, the lengthy process of integration into the official community (the International Psychoanalytic Association, IPA), and the force of retraction felt by the new psychoanalytic generation in each country as they experienced feelings of loneliness, separation, and being "enclosed." These feelings all originated from economic backwardness, legal restrictions on making international contacts, and the experience of "exclusion by language." The consequence was a deficit of self-esteem and a painful feeling of being second-class analysts in the international community.

\section{Historical antecedents to the situation of psychoanalysis in these countries}

The Hungarian psychoanalytic movement experienced two great setbacks due to the political emigration of intellectuals (Frank, 2009) in the quarter-century between the two World Wars; both these waves of emigration, in the early 1920s and between 1938 and 1941, were the result of outbreaks of anti-Semitism and laws discriminating against Jews (Mészáros, 2014). These attacks, however, were made against analysts of Jewish descent, not against psychoanalysis as a discipline. Being a committed leftist or communist as well as Jewish led to a multiple disadvantage.

After 1945, the Soviet liberation of the region also represented its Soviet occupation. The former Yugoslavia was an exception among the countries discussed here, because no Soviet troops were posted there and it was not included among the countries which would come to be known as the Iron Curtain. In countries such as Hungary and the former Czechoslovakia which were under Soviet control, ideological pressure was brought to bear on psychoanalysis because of the Soviet influence. Psychoanalysis was viewed as a hostile product of western civilization, and as "the domestic psychology of imperialism" it was placed on a list of disciplines to be stamped out (Mészáros, 2010, 2012). Governing bodies of the Yugoslav Communist Party would basically exert the same policy, albeit independently; doctoral dissertations in the field of psychoanalysis at the Belgrade University Department of Psychology were rare and suspected of western and bourgeois influence. ${ }^{1}$ The ideologists of these regimes regarded it as backwards, bourgeois, individualistic pseudo-science and dismissed it as serving the interests of imperialism. After Stalin's death in 1953, a new period began in the Eastern Bloc countries. Occasional uprisings (East Germany in 1953, Hungary in 1956, the Prague Spring in 1968, and the 1980-1981 Solidarity movement in Poland) were crushed one after the other by the Soviet Union, which dominated the region; consequently, several generations lived and were socialized for long decades within the ideological, political, and economic isolation of a totalitarian and later dictatorial regime. During this era, Yugoslavia 
differed from the other Soviet Bloc countries; from a political and economic point of view, it was the most liberal communist country, even though it contained no political pluralism and the federal structure was controlled by the Communist Party.

During Hungary's political thaw between the 1960s and 1980s, the country's cultural policy was determined by guidelines famously dubbed the "three Ts" (for the Hungarian words for "subsidize," "tolerate", and "ban") and was used to lure and punish leading members of the intelligentsia. It was in this environment that psychoanalysts - who until then had been completely fragmented and driven underground - gradually set up seminars, but they were forced to organize from scratch because of their decades-long break with the International Psychoanalytic Association. As a result of political pressure and recommendation from its own leadership, the Hungarian Psychoanalytical Society dissolved itself at its general meeting in early 1949 and the society consequently ceased to exist as an institutional framework. Most members, however, carried on in the professions for which they had originally been trained, such as physicians and teachers. The fragmented mode of operation, followed by 25 years without institutional support, forced the small remaining group of Hungarian analysts to start from the very beginning in their effort to integrate into the international mainstream. A study group was established in 1975 with the support of the IPA. Because of the divergent historical antecedents of psychoanalysis in Belgrade and Prague, similar study groups would only be established in the 1990s.

\section{Differences and similarities}

The reception and roots of psychoanalysis in each of these countries date back to different periods of the twentieth century, and consequently the rebirth of the field drew on divergent sources in the past.

What are the differences and what are the common denominators in the international reintegration of psychoanalysis in Budapest, Prague, and Belgrade? The history of development between the 1970s and 1990s cannot be understood without considering the losses suffered in the 1930s.

The Hungarian Psychoanalytical Society was one of the oldest and most prestigious societies in Europe, while psychoanalysis emerged in Prague and Belgrade in the late 1920s and mid-1930s (Hristeva, 2013). In both Belgrade and Prague certain people were committed to the new view of psychoanalysis, but the structure of a psychoanalytic community/society could not be strengthened because of the political and societal turmoil from the 1930s.

I must note that despite the difficulties generated by the two waves of emigration - at the beginning of the 1920s and at the end of the 1930s, which caused serious losses to Hungary's psychoanalytic community - the Hungarian Psychoanalytical Society managed to maintain stable operations. This is all the more remarkable because emigration, which was the direct consequence of anti-Jewish regulations and laws (1920, and from 1938) in Hungary, represented a serious loss to the Budapest psychoanalytic community. 


\section{Restricted options in Europe: exile from Berlin}

After Hitler came to power, the lives of Jewish psychoanalysts within the Berlin Society came under threat, and consequently many resorted to involuntary emigration. This group included Freudian leftist/Marxist analysts and members of the Children's Seminar (Kinderseminar), who were obliged to leave Berlin immediately because of their Jewish origin as well as their political inclinations. A considerable number of analysts in the Berlin Psychoanalytic Society and Institute escaped to Prague: these included Frances Deri and Annie Reich (both Austrians), the German Steff Bornstein; the Hungarian Edith GyömröiGlück (Ludowyk), the originally Slovak Emanuel Windholz (who had previously been to Prague), and the Viennese Otto Fenichel (the charismatic leader of the Children's Seminar) (Kwawer, 2003).

This incomplete list itself demonstrates that, for a combination of political and professional reasons in Europe in the 1920s and 1930s, there was continuous migration/emigration from the Hungarian and Vienna Psychoanalytic Societies to the Berlin Psychoanalytic Society and Institute. The spread of National Socialism, however, imposed an exile which by then reached to all corners of the globe and soon afterwards concentrated in the direction of the United States.

\section{Prague in the 1930s}

Sándor Ferenczi would have liked one of his talented analysands, Sándor Lóránd, to be an ambassador to Czechoslovakia for psychoanalysis. However, this plan fell apart as Lóránd, like so many Hungarian psychoanalysts, left the country in the wave of emigration that swept the 1920s. Lóránd was the first to leave Hungary and move beyond Europe to re-settle across the sea in New York City. The analysts who emigrated from Berlin after Hitler came to power in 1933 - together with some other analysts who had been active in Prague previously (Nikolai Osipov, Emanuel Windholz and Bohodar Dosuzkov) - and represented a significant source to establish the psychoanalytical group in Prague (Kitlitschko, 2013). Martin Mahler (2013) has characterized this period as follows: "immigrants from the Western and Eastern totalitarian regimes - Nazi Germany and the Bolshevik Soviet Union - deserve the credit for the origins of Czech psychoanalysis. The young Czechoslovakia was still both German and Slavic enough for these refugees to continue their work ... the origins of Czech psychoanalysis are, in fact, international". A Czecho-Slovakian study group, which was affiliated with the Vienna Society, was accepted by the IPA at the Lucerne Congress in 1934.

In the pages of the International Journal of Psychoanalysis, Glover (1937) reported that IPA president Ernest Jones commented in his opening speech at the International Psychoanalytical Congress in Marienbad in 1936 that it was the first time an IPA congress had been held in a country without a psychoanalytical institute or even a society. As he put it, "We are venturing on to almost virgin soil, though one that promises to be fruitful soil. I say 'almost virgin,' since we have for some years been preceded by a few individual analysts" (p.72).

During their desperate plight brought on by Nazism, many sought refuge in countries still seen as free, and paradoxically it was this wave of refugees that led to the formation of the 
Prague Group. Jones himself placed the emergence of psychoanalysis in the Czech capital into a historical context by noting that the Russian analyst Osipov was the first to leave the newly-formed Soviet Union and re-settle in Prague (in 1923). "The first Czech physician to practise psycho-analysis, since 1928, was Dr. Windholz. Then, under the leadership of Frau Deri, until she left for America last year, a Study Group was formed, which we affiliated with the Vienna Society. This has been recently strengthened by the accession of 'one of our most valued members ... Dr. Fenichel'" (Jones cited in Glover, 1937, p.72; emphasis in the original). Otto Fenichel, who bore a double burden in the Germany of that era as both a Jew and a Marxist psychoanalyst, was forced to escape Hitler's reign, first to Oslo and then to Prague (in 1935). Finally, in 1938 he left an ever more perilous Europe behind and re-settled in Los Angeles.

However, in 1936 Jones still underlined the "promising future" of psychoanalysis in Czechoslovakia "in one of the few states in Europe, where the most necessary condition [for psychoanalysis] ... freedom" existed. A country "surrounded by countries whose professors have to submit to the censorship and direction of arbitrary dictators" (Jones cited in Glover, 1937, p.72). This "promising future," however, only lasted a few years until the German occupation of Bohemia in 1939. Many members of the group immigrated to the United States (including Emanuel Windholz, one of the first psychoanalysts in Prague, who settled in San Francisco) while a number lost their lives in the concentration camps. Among the survivors was Bohodar Dosuzkov, who "became the symbol of post-war underground psychoanalysis during the Communist period" (Šebek, 1999, p.987). The Prague group had existed for several years before World War II and for three years afterward. Later, psychoanalysis in Czechoslovakia was banned until the fall of the Iron Curtain.

\section{Belgrade from the 1910s}

Psychoanalysis arrived to Belgrade in 1914, when Nikola Popovic abandoned his studies at the Humboldt University to volunteer in the defense of Serbia in World War I and brought his psychoanalytic texts. Popovic became a professor of philosophy and Dean of the Faculty of Philosophy, translated Freud, Adler and Jung, and wrote a book on psychoanalysis in 1934 (Mirić, 2010).

This book was reviewed in the psychoanalysts' international journal by an extremely important figure in the development of clinical psychoanalysis in Serbia (Sugar, 1938). Nicola Sugar was a physician, born Miklós Sugár to a Jewish family in the Hungarian town of Szabadka (after 1918, Subotica in Serbia), ${ }^{2}$ who sowed the seeds of psychoanalysis in the capital of the former Yugoslavia. Because of the anti-Semitism stirred up in Hungary, the number of Jewish students permitted to study at university was slashed to $6 \%$ after the closed number (numerus clausus) law in the 1920s. Sugar was consequently not admitted to the Medical School at the Budapest University, and because of anti-Semitism in Austria he was also denied entry to the Vienna School of Medicine. He eventually obtained a university degree in Prague, became a psychoanalyst in Vienna, and then returned to Yugoslavia (Klajn, 1997). Sugar founded the Belgrade Psychoanalytic Study Group in 1937 with eight members (Glover, 1939); the group only operated for a few years until the German occupation of the country in 1941. 
Nevertheless, the promising development of psychoanalysis suffered a great setback when Sugar lost his life in the Bergen-Belsen concentration camp a few days before the Americans arrived in 1945 (Harmat, 1989). His analysand and disciple Vojin Matić (1911-2000) founded a counseling service based on psychoanalytic principles in the late 1950s. When this service was closed by the communist authorities, Matić became a professor at the Belgrade University Department of Psychology (even though he was a medical doctor) and introduced courses on psychotherapy, counseling, mental hygiene, and developmental psychopathology, and published several books on psychoanalysis applied to ethnology and archeology.

For a long time Matić was the only psychoanalyst in Belgrade, and analyzed many psychologists and psychiatrists. His self-sacrificing work was continued in the 1980s and 1990s by a young, blossoming generation open to psychoanalysis. Under the leadership of Tamara Štajner Popović, these professionals created the institutional framework for psychoanalysis in Belgrade. Sixty years after the first study group, the second study group joined the IPA in 1996; this developed to found the Belgrade Psychoanalytical Society, which became a component society of the IPA in 2007 (Kordić, 2011).

\section{Zagreb from the late 1920s}

The early history of psychoanalysis in Zagreb is linked to the name Stjepan Betlheim (1898-1970), who was born in the city. He studied medicine in Graz and Vienna, and became psychiatrist and neurologist in Berlin and Paris. During his years in Vienna he became interested in psychoanalysis and attended Freud's lectures. His analysts were Paul Schilder and Sandor Rado (originally from Hungary). Betlheim became an associate member (1929) and later a full member (1937) of the Vienna Psychoanalytic Society. He returned to Zagreb in 1928, where he educated and analyzed generations of younger colleagues. After World War II, he introduced the psychodynamic approach to mental disorders in working with psychiatric patients at the Neurological-Psychiatric Clinic at the University of Zagreb School of Medicine and helped publish psychoanalytic texts. In the early 1950s he became an independent member of the IPA (1953), a classification known at that time as "Member at large" which was created for those members who were unable to join a local group. Croatia, with its largest city Zagreb, was also part of the former Yugoslavia. After Betlheim's death, the development of psychoanalysis was interrupted and only continued in Slovenia and Croatia in the 1990s, under the auspices of the IPA and the European Psychoanalytic Federation (EPF) with invaluable support from Paolo Fonda (Trieste) and the Venice Centre (Gibeault, 1996). Fonda and his Italian colleagues analyzed and supervised the members of the following generation who established the psychoanalytic study group in 2004.

\section{Rebirth and development of psychoanalysis from 1970 to 1989: Budapest, Prague and Belgrade}

The development of psychoanalysis between 1970 and 1989 - until the fall of the Berlin Wall (in 1989) and the Iron Curtain (in 1990), which had once formed a military, political, 
and ideological barrier between the Soviet Bloc and western Europe - differed widely in Belgrade, Prague and Budapest.

Belgrade's political and economic position was unique. The former Yugoslavia was never occupied by the Soviet Army; although the autocratic Communist Party built a totalitarian system there, it did not restrict human rights in those years, nor did it centralize the economy to the extent that Soviet-type dictatorships did in the Eastern Bloc countries they controlled. There were no harsh political prohibitions against psychoanalysis. Life in the former Yugoslavia was relatively free in terms of the economy and the freedom to travel abroad, for example.

In Prague, the psychoanalytic group developed promisingly from immediately after World War II to 1948, when "the communist putsch destroyed all hopes. Psychoanalysis... became illegal, a situation that lasted 41 years" (Šebek, 1993, p.434). During the years of political consolidation in the 1970s, psychoanalysts also facilitated the psychotherapeutic movement and group psychotherapy. Some professionals who were trained in group therapy "entered training in psychoanalysis organized by the Prague group in the 1970s and 1980s" (Šebek, 1993, p.435). This group created a system for education and training.

An important event linked together Prague and Budapest in these years; in 1987 the Hungarian Psychoanalytical Society organized the first international psychoanalytic conference after World War II in Budapest, and representatives of the Prague psychoanalytic group also attended. This event became a "turning point... stimulated outside interest in Czechoslovakian psychoanalysis" (Šebek, 1993, p.436). Afterward the Prague group was supported by important figures from the IPA, who organized training analysis and supervisions. The independent Czech Psychoanalytical Society was established in 1990, and soon after the study group was set up in 1993, and the Czech Psychoanalytical Society became a component society of the IPA in 2004.

Budapest attempted to rebuild from the ruins of a fragmented historical legacy. Despite all the losses, some analysts still maintained continuity with the psychoanalytical community from before World War II and represented their teachings to future generations. Sporadically during the 1960s and 1970s, some psychoanalysts from the former Budapest School who had remained in Hungary began to organize seminars; most influential was the group around Imre Hermann.

A slow reintegration began in 1975, when the fragmented circle of psychoanalysts set up a study group. This group comprised five psychoanalysts, ${ }^{3}$ and was led by doctor György Hidas. It was not until 1989 that the Hungarian Psychoanalytical Society again became a full member of the international psychoanalytic community and a component society of the IPA.

Besides personal continuity, the legacy of the Budapest School inspired the resumption of theoretical work. Nevertheless, from his death in 1933 until the end of the 1970s, Sándor Ferenczi (the leading figure of the Budapest School) was surrounded by a kind of Cold War silence and rejection, the result of a personal rivalry initiated and maintained within the psychoanalytical movement by Ernest Jones. Jones believed (and wrote in his famous biography of Freud) that Ferenczi had suffered from mental illness towards the end of his life and that his latter papers were worthless (Jones, 1957; Dupont, 1988; Bonomi, 1998). It is no accident that the Hungarian psychoanalysts of the 1960s and 1970s who pursued their 
professional activity underground now chose different "father figures:" Sigmund Freud, and Imre Hermann from the Budapest School circle.

Ferenczi only had a positive reception after the beginning of the so-called Ferenczi Renaissance. The Sándor Ferenczi Society played an important role in advancing his reputation since it began operating in Hungary in the late 1980s (it was founded in 1988), in close cooperation with ever more complex, international-level Ferenczi research projects and with a rapidly developing international Ferenczi network. From the beginning, some specific characteristics of the Ferenczi Society permitted this quick development. First, it was not a training society for psychoanalysts; the society was interdisciplinary and was open to members of any scientific discipline, as long as these had a dialogue with psychoanalysis. Members of the society conducted research on the theory and history of psychoanalysis. Additionally, the society also offered forums, organized international conferences, and had its own periodical: Thalassa published historical, theoretical, clinical, and critical papers dealing with problems shared by psychoanalysis and the humanities.

Speaking of books: before the digital revolution, books represented knowledge. In these countries during the darkness of the Soviet regime, no one could find or read books on psychoanalysis in the libraries. In the 1970s, the problem was finding new books. Starting in the late 1980s, translation and publication of basic and new books slowly began.

\section{Common denominator: separation and a deficit of self-esteem}

The common denominator among the analysts in each group in these countries was a feeling of loneliness, separation, and being enclosed, which led to a serious deficit of selfesteem. This was accompanied by the "restriction of movement," which partly originated from economic backwardness, and the experience of "exclusion by language" which is characteristic of societies which have been closed for decades. This applied especially to Hungary: since the 1960s western languages were an option in schools alongside mandatory Russian courses, but since there was no free movement to western countries, these languages basically remained "dead." This also damaged the potential for later generations of psychoanalysis to make international contacts and further decreased individual self-esteem.

Another factor that also fits into the common denominator is that "psychoanalysis cannot develop in Eastern Europe without substantial help from the West, organized by committees and subcommittees of the IPA and the EPF" (Šebek, 1999, p.983). Psychoanalysis was internationally reintegrated through professional and financial support channeled through representatives of the IPA and the EPF in the Eastern European countries.

Since psychoanalysis, unlike other sciences, has not been integrated into academic structures or a university curriculum, where even today its presence is rather incidental all over the world, the organizational structure of national and international societies is of the utmost importance. This structure represents a professional umbrella. Like all institutional systems, this can be criticized, but the lack of connection has always presented the danger of professional marginalization. This is why the modern chapter of the Yugoslav Wars (1991-1999) that led to the disintegration of Yugoslavia was so noteworthy for the Belgrade Psychoanalytical Society. People had not experienced this in Tito's Yugoslavia, but this process 
took place in other Eastern European countries during their transitional periods after the fall of the Berlin Wall. In the first half of the 1990s, when

Serbian communist nationalism and its ideology prohibited citizens from having any interactions with foreigners, ... the Belgrade group [found itself] as a millstone between the local pressure of the State leading a rightful war against all-encompassing enemies and members' need for foreign assistance, without becoming highly treasonous to the State. In addition, the possibility of accepting the IPA's help had been endangered by colleagues from former component countries of Greater Yugoslavia demanding that the EPF and the IPA exclude Serbians from Eastern European seminars, because their country was subject to UN sanctions (Mikota, Štajner-Popović, 2005, p.546).

Despite its complexity, historical research is undoubtedly simpler than answering questions about the impact a totalitarian regime had on a specific group and its dynamics, which clearly show the impact totalitarian systems have on individuals. It is no accident that the exploration, discussion, and management of these very processes pose difficulties for Eastern European psychoanalytical societies. Initiatives have been put into motion, come to a standstill, and occasionally taken on a new impetus. Of course, the local history of psychoanalysis is closely tied to the processing or unreflected encapsulation of the modern history of a particular country.

It goes without saying that totalitarian regimes consciously and unconsciously determine the sensitivity and capacity of psychic realities; totalitarian systems favor denial. The negative symptoms/contradictions of the system either "do not exist" or are projected as undesirable phenomena, generating a paranoid atmosphere that leads to the creation and maintenance of an enemy image. Furthermore, the operation of totalitarian/dictatorial societies can be characterized as a dichotomy: the supporters of the system are good, while the others are bad (enemies). Clearly the perception and sense of reality among persons who live in or are born into such a society will be distorted in some way, which can be further corrupted by the dictatorial system's set of tools, the expropriation of the media, and the restriction of human rights and liberties, including contact with other, non-totalitarian systems. Under these circumstances, individual autonomy is violated and false self-images evolve. Totalitarian systems support the incorporation of false internal self-objects. They decrease the individual's receptiveness to other points of view, which hinders the establishment of dialogues and compromises. In the long run, these systems orient individuals towards either identifying with the system or extreme revolt. Together with several other factors, strengthening one pole serves to maintain the system, while strengthening the other works to collapse it.

In several studies, Michael Šebek has discussed how a totalitarian political system is reflected in the unconscious mind and how totalitarian systems are internalized in the personality. He named these internalized self-objects "totalitarian objects" (Šebek, 1996), and listed the effects internalizing external totalitarian objects can have on the personality. Among other consequences, totalitarian objects diminish or fail to tolerate differences from other objects and facilitate identification with omnipotent/narcissistic objects. Since the system is dogmatic, the totalitarian object destroys creativity and suppresses dialogue. One of the consequences of the existence of a totalitarian object in the inner psychic structure was that after the external enemy (Soviet control) disappeared, the nationalist/rightist portion of Hungarian 
society began to seek out new/old enemies based on prejudice (Jews, communists, foreign capital, the EU etc.). This kind of unassumed national responsibility for mistakes and decisions in the country's own history reinforces its false self-image as a victim, which results from a narcissistic adherence to trauma. A partially similar process has been noticeable in Czech society. "For decades, it has become a common understanding and self-interpretation that the Czechs are victims of a foreign influence. This victimization spared them all responsibility and contributed to their tendency to search for culprits elsewhere, allowing them to reject their part in causing their symptoms" (Mahler, 2013).

Many psychoanalytical societies in dictatorial regimes faced low self-esteem, expressed in the feeling that members were "second-class" analysts, for example. In a survey, Hungarian analysts and candidates "assessed the members of the old [psychoanalytic] society significantly above the international average, while they put those of the new society significantly below the level of the international average in 1987. This feeling characterized the Hungarian psychoanalytic community amidst the reintegration process in the 1970s and 1980s" (Szönyi, quoted in Mikota, Štajner Popović, 2005, p.544).

Whether they discussed it or not, a great deal of unprocessed emotion appeared in the group dynamics of the psychoanalytical societies. The Czech society was able to articulate the problem, however: "Having got rid of the former background of the totalitarian regime, the members of the Czech group appeared to be unable to manage their newly discovered mutual hatred for some time" (Mikota, Štajner Popović, 2005, p.545). In the transitional period in the early 1990s, "There were no serious problems of developing 'psychoanalysis' [as a discipline]... but the growing hatred within the group was the major obstacle to forming an organised society" (p.545; emphasis in the original).

We cannot ignore the personal tragedies that the Jewry of the particular countries suffered at the time of the Nazi dictatorship because of the German invaders and collaborators or Fascist dictators in these countries. In the Soviet Bloc, the ideology of a politically different dictatorial system hindered survivors from processing their tragedies. For example, as members of the Communist Party, those who survived the Holocaust ceased to be Jews. The party, packaged into the ideology of human equality, demanded that its members completely surrender their previous identities, including religion and ethnicity. This resulted in unprocessed traumas and transgenerational transfer of resulting impacts, and applied to analysts and consequently to the group dynamics of analytic communities as well.

As a result, by the 1960s and 1970s a two-directional process prevailed. Unprocessed traumas and losses were accompanied by the personality-distorting effects of Soviet-type dictatorships. These processes came to the focus of research mainly because of the changes that took place in the 1990s, but were much less present in the wide-ranging examination of historical and social processes in Hungary, for example.

Because of the traumas and losses suffered, Michael Šebek $(1999$, p.984) believes that Eastern European psychoanalytic groups "try to discover and explore the 'lost-family' of prewar psychoanalysts, or have referred to underground analytic 'parents' in order to find some basis for a contemporary psychoanalytic identity." Authoritarian or totalitarian systems offer father figures who initially step up as leaders or advocates and defenders of the legitimate or presumed needs of ordinary people, and these finally become integrated into the psychological 
operation of individuals as "paternal imagos" endowed with omnipotent characteristics. As far as the father figure issue is concerned, we must note that both the structure of the psychoanalytical movement and Freud, the creator of psychoanalysis himself, displayed a considerably authoritarian mode of operation. Freud did not tolerate alternative thinkers (see Jung and Adler in the early movement or the internal dynamics of the Freud-Ferenczi conflict later). Therefore, the roots of the search for a "father figure" by psychoanalysts originate from several sources. It is nevertheless undeniable that civil society grew weaker in the Eastern European countries, and restraining the autonomous and sovereign development of the individual was in itself favorable to incorporate and maintain an authoritarian, omnipotent, and idealized paternal image.

While the totalitarian state exercised control functions with dictatorial tools in many areas of civil society, the dissolution of psychoanalytic societies resulted in weakened professional control for psychoanalysts pursuing underground or semi-underground activities.

In the history of psychoanalysis, psychoanalytic societies and institutions not only had holding power, but they also ensured the quality of professional training and control functions. In countries where analysts were compelled to operate underground, they faced not only increasing professional isolation but also the failure of institutional feedback and control. This sometimes led to corruption of the analysts' super-ego structures (Mahler, 2013). The notion of establishing institutional structures had long blurred with negative experiences originating from the institutional operation of totalitarian systems, which explains why analysts later feared developing institutional systems. During the late 1980s in Budapest, analysis displayed notable resistance to institutional connections over the course of a long integration process which followed the establishment of a study group in 1975. The "analyst is individually nice ...; the analytical society is hateful... [and there was also] fear of theoretical debates; fear to show one's own work" (Mikota, Štajner Popović, 2005, p.544).

Conspiracy was embedded in the rules of underground activity, which even today makes research difficult. Martin Mahler (2013), the recent president of the Czech Society, has stated, "Still to this day, it is not clear what ... happened to the document that became so significant to our history ... It is understandable that much of the psychoanalytic group's knowledge was preserved purely in memory." This phenomenon has been observed in other psychoanalytic groups in other countries as well. The Czech Society established a study group in 1993 and became a full member of the IPA in 2004.

We are still far from being able to provide a full (let alone complex) picture of what happened between the 1970s and the 1990s in the ex-Soviet Bloc countries while psychoanalysis operated underground or on a semi-underground basis. But we already know a great deal about which forces supported or hampered the reestablishment of psychoanalytic groups amidst the anti-psychoanalytic political climate of specific countries. In Budapest, for example, the study group that embodied revival was founded approximately two decades ahead of those in Prague or Belgrade, but it took twice as long for Budapest to achieve full membership status in the IPA as it did for Belgrade or Prague (see Table 1 and 2). 
Table 1: Status of psychoanalytic groups and societies in Budapest, Prague and Belgrade, 1900-1948

\begin{tabular}{l|c|c|c|c}
\hline \multicolumn{1}{|c|}{ Study-1948 group } & $\begin{array}{c}\text { Provisional society } \\
\text { of the IPA }\end{array}$ & $\begin{array}{c}\text { Component society } \\
\text { of the IPA }\end{array}$ & $\begin{array}{c}\text { Dissolution of the } \\
\text { group/society }\end{array}$ \\
\hline Budapest & & & 1913 & 1949 \\
\hline Prague & 1934 & & & 1939 \\
\hline Belgrade & 1937 & & & 1941 \\
\hline
\end{tabular}

Source: Elaborated by the author.

Table 2: Status of psychoanalytic groups and societies in Budapest, Prague and Belgrade, 1970-2013

\begin{tabular}{l|c|c|c}
\hline 1970-2013 & Study group & $\begin{array}{c}\text { Provisional } \\
\text { society of the IPA }\end{array}$ & $\begin{array}{c}\text { Component } \\
\text { society of the IPA }\end{array}$ \\
\hline Budapest & 1975 & 1987 & 1989 \\
\hline Prague & 1993 & & 2004 \\
\hline Belgrade & 1996 & & 2007 \\
\hline Croatia (Zagreb) & 2004 & 2013 & \\
\hline
\end{tabular}

Source: Elaborated by the author.

\section{Final considerations}

The political and ideological rejection of psychoanalysis varied in intensity during the 1960s and 1980s in Hungary, Czechoslovakia, and Yugoslavia. In places where the field enjoyed strong roots, it was easier to maintain sufficient continuity for forty years even without institutional support, making it possible to nurture the growth of a new generation of psychoanalysts in the 1970s. The personality-distorting influences on the newly-established psychoanalytic groups and societies can be observed in all these countries; research and fuller understanding of these influences await the current generation.

\section{NOTES}

${ }^{1}$ Information from Aleksandar Dimitrijevic.

${ }^{2}$ Szabadka was a Hungarian town under the Austro-Hungarian monarchy. After 1918, it became part of the former Yugoslavia and was named Subotica. Today it is part of Serbia.

${ }^{3}$ Members of the study group: György Hidas, Adorján Linczényi, Lívia Nemes, Gábor Paneth, and György Vikár.

\section{REFERENCES}

BONOMI, Carlo.

Jones's allegation of Ferenczi's mental deterioration: a reassessment. International Forum of Psychoanalysis, v.7, n.4, p.201-206. 1998.
DUPONT, Judith.

Ferenczi's "madness". Contemporary

Psychoanalysis, v.24, n.2, p.250-261. 1988. 
FRANK, Tibor.

Double exile: migrations of Jewish-Hungarian professionals through Germany to the United States, 1919-1945. Bern: Peter Lang; European Academic. 2009.

GIBEAULT, Alain.

Activities of component organisations, 19931995. Bulletin of the International Psycho-Analytical Association, v.77, p.190-212. 1996.

GLOVER, Edward.

Report of the International Training Commission. Bulletin of the International PsychoAnalytical Association, v.20, p.220-221. 1939.

GLOVER, Edward.

Report of the Fourteenth International PsychoAnalytical Congress. Bulletin of the International Psycho-Analytical Association, v.18, p.72-107. 1937.

HARMAT, Paul.

The holocaust of Hungary's psychoanalysts. Journal of the American Academy of Psychoanalysis and Dynamic Psychiatry, v.17, n.2, p.313-319. 1989.

HRISTEVA, Galina.

A dream of freedom: the correspondence of Sigmund Freud and Nikolay Y. Ossipov 19211929. Journal of the American Psychoanalytic Association, v.61, n.3, p.511-525. 2013.

JONES, Ernest.

The life and work of Sigmund Freud. v.3: the last phase, 1919-1939. London: The Hogarth Press. 1957.

KITLITSCHKO, Susanne.

The Prague Psychoanalytic Study Group, 19331938: Frances Deri, Annie Reich, Theodor Dosužkov, and Heinrich Löwenfeld, and their contributions to psychoanalysis. International Journal of Psycho-Analysis, v.94, n.6, p.1196-1198. 2013.

KLAJN, Peter.

Sugár Miklós és a szerbiai pszichoanalízis fejlődése [Miklós Sugár and the development of Serbian psychoanalysis]. Thalassa, v.2, n.3, p.129-153. 1997.

KORDIĆ, Boris.

Istorija psihoanalize $\mathrm{u}$ srbiji $\mathrm{u} X \mathrm{XX}$ veku [The history of psychoanalysis in Serbia in the twentieth century]. Engrami, v.33, n.1, p.93-105. 2011.

KWAWER, Jay S.

Psychoanalysis in Nazi Germany. Contemporary Psychoanalysis, v.39, n.2, p.299-323. 2003.
MAHLER, Martin.

Czech psychoanalysis and concept of external reality. Paper presented at the 48th International Psychoanalytical Association Congress, 2013. Prague. 2013.

MÉSZÁROS, Judit.

Ferenczi and beyond: exile of the Budapest School and solidarity in the psychoanalytic movement during the Nazi years. London: Karnac. 2014.

MÉSZÁROS, Judit.

Effect on dictatorial regimes on the psychoanalytic movement in Hungary before and after World War II. In: Damousi, Joy; Plotkin, Mariano Ben (Org.). Psychoanalysis and politics: histories of psychoanalysis under conditions of restricted political freedom. New York: Oxford University Press. p.79-108. 2012.

MÉSZÁROS, Judit.

Progress and persecution in the psychoanalytic heartland: anti-Semitism, Communism and the fate of Hungarian psychoanalysis. Psychoanalytic Dialogues, v.20, n.5, p.600-622. 2010.

MIKOTA, Václav; ŠTAJNER-POPOVIĆ, Tamara. Developing psychoanalysis under socio-political pressure: viewpoints from Eastern Europe. International Journal of Psycho-Analysis, v.86, n.2, p.543-546. 2005.

MIRIĆ, Jovan.

How psychoanalysis arrived to the Kingdom of Serbia: interview. Psihijatrija danas, v.42, n.1, p.85-91. 2010.

PLOTKIN, Mariano Ben; DAMOUSI, Joy.

Psychoanalysis and politics: historical perspectives. Psychoanalysis and politics: histories of psychoanalysis under conditions of restricted political freedom. New York: Oxford University Press. p.X-XXX. 2012.

ŠEBEK, Michael.

Psychoanalytic training in Eastern Europe.

Journal of the American Psychoanalytic Association, v.47, n.3, p.983-988. 1999.

ŠEBEK, Michael.

The fate of the totalitarian object. International Forum of Psychoanalysis, v.5, n.4, p.289-294. 1996.

ŠEBEK, Michael.

Psychoanalysis in Czechoslovakia. Psychoanalytic Review, v.80, n.3, p.433-439. 1993.

SUGAR, Nikola.

Predavanja iz psihoanalize [Lectures on psychoanalysis]: By M. Nikola Popovic (Verlag Geza Kon, Belgrade, p.296. 1934.). International Journal of Psycho-Analysis, v.19, p.242-244. 1938. 